\title{
Review
}

\section{What animals teach us about politics}

\author{
Brian Massumi \\ Duke University Press, Durham, 2014, 152pp., ISBN: 978-822358008 \\ Contemporary Political Theory (2015) 14, e25-e27. doi:10.1057/cpt.2015.2; \\ published online 10 February 2015
}

What Animals Teach Us about Politics is a work of agile, unorthodox thinking at the intersection of political theory and critical animal studies. In lucid and compact prose, the volume draws together currents in evolutionary biology, process philosophy, and affect theory to provide an original account of animality centered on the concept of play - an account ripe with political implications. As with Massumi's previous original work, the influence of Deleuze and Guattari is strong throughout the text. Even so, the account of animality Massumi develops is distinct from, if ultimately consistent with, the account of becoming-animal supplied by Deleuze and Guattari in their 1980 classic A Thousand Plateaus, which Massumi translated into English in 1987.

The structure of What Animals Teach Us about Politics is unusual, though fitting to the experimental character of Massumi's approach. The volume's main, titular essay runs just over 50 pages, culminates in 14 programmatic 'propositions,' and is followed by three 'supplements' of varying lengths, each of which addresses an additional topic related to the main essay. The main essay is described as 'an extended thought experiment in what an animal politics can be' (p. 3). Massumi distances his position from any form of political anthropocentrism at the outset, specifying that this is not a human politics of the animal, but an integrally animal politics, freed from the traditional paradigms of the nasty state of nature and the accompanying presuppositions about instinct permeating so many facets of modern thought' (p. 2).

The three supplements at the volume's end each build on the main essay and present i) a differentiation of Massumi's account of play in non-human animals from Deleuze and Guattari's concept of becoming-animal in humans, ii) a critique of zoos, inspired by the fact that Gregory Bateson - whose mid-twentieth century ecoanthropological theory of animal play is the central reference point of the main essay arrived at his ideas after a visit to the San Francisco Zoo, and iii) a succinct series of anti-propositions that Massumi labels 'Six Theses on the Animal to Be Avoided.' In overview, the main essay first develops a novel account of animality based on the concept of play and then articulates a vision of animal politics based on it, while the three supplements offer more occasional extensions or applications of the 'thought experiment' that precedes them.

(C) 2015 Macmillan Publishers Ltd. 1470-8914 Contemporary Political Theory Vol. 14, 4, e25-e27 www.palgrave-journals.com/cpt/ 
So what do animals teach us about politics? Readers expecting a straightforward response to this question in the initial pages of What Animals Teach Us about Politics may be frustrated. Dispensing with either preface or introduction, and with little signposting, the body of the main essay (roughly three dozen pages) synthetically constructs its account of animality by weaving together a range of concepts drawn from a variety of disciplines: mutual inclusion, zones of indiscernibility, expressivity, sympathy, and, above all, play. Against the traditional mechanistic picture of animal life as blindly, predictably instinctual, Massumi insists on the primacy of spontaneity, vitality, and creativity in the immanent development of life, even within instinct itself (p. 19). Bateson's theory of play provides the touchstone for Massumi's account, though concepts from Raymond Ruyer ('aesthetic yield'), Henri Bergson ('transindividuality'), and Niko Tinbergen ('supernormal stimuli') are also treated in some depth.

Massumi's style is confident and fluid. Rarely does he pause to qualify the steps of his thinking. Interested readers will find such qualification, however, in Massumi's running endnotes, which are characteristically astute. There are no subheadings or section breaks within the main essay, except to introduce the set of 14 'propositions' that bring the essay to a close. Occasionally cryptic, and ranging from a single sentence to several pages in length, it is within these propositions that Massumi ventures his view of what animals teach us about politics. As with the account of animality that grounds it, this view is difficult to encapsulate, and there turns out to be no single, overarching political lesson that animals teach us. Moreover, though they appear in a numbered sequence, the logic connecting one proposition to the next, as may be expected from readers familiar with Massumi's Deleuzian commitments, is non-linear.

Animality, understood in and through play, yields a new form of 'animal politics,' one that 'cannot be based on normative ethics of any kind' (p. 38) but that is 'a politics of becoming, even - especially - of the human' (p. 50). This is not a special politics for non-human animals, but a refiguring of politics as such around animality. The 'political animal,' a fixture of political theory since Aristotle, is resurrected in Massumi's vision as the 'processual subjectivity-without-a-subject' (p. 41) behind political activity. Needless to say, though this cannot be further substantiated here, this animal politics is non-agential, non-representational, and non-normative, though, Massumi reminds us, it 'is not without criteria of evaluation' (p. 41). Though the 14 propositions are mostly declarative, Massumi also has occasion to defend his view of animal politics from the charge of anthropocentric projection and to distinguish his position, either in detail or in passing, from the apparently proximate positions of Latour, Harman, Meillassoux, and Agamben.

While the positions staked out in Massumi's book will likely appeal most to readers already sympathetic to affect theory, vital materialism (Jane Bennett's Vibrant Matter is a natural companion text), or the thought of Deleuze and Guattari, What Animals Teach Us about Politics arguably contributes most decisively to the still developing field of what might be called 'political animal studies.' Several recent releases in this area have similarly attempted to rethink the political status of animal 
life. Consider Sue Donaldson and Will Kymlicka's much-discussed Zoopolis: A Political Theory of Animal Rights. Donaldson and Kymlicka advance the idea that animals should be seen to have not only a set of negatively defined basic rights, such as the right to noninterference, but also an expanded pallet of positively defined political rights that bring animals 'into practices of citizenship' (2013, p. 15) and where our treatment of animals connects 'more directly to fundamental principles of liberal-democratic justice and human rights' (2013, p. 3). While Massumi's revisioning of the political animal may align with the ends of Donaldson and Kymlicka's project - both call for animals to be thoroughly integrated into the political landscape - Massumi's many non-liberal commitments, such as his rejection of agency and subjectivity, place him fundamentally at odds with any approach to animals rooted in a strong conception of rights - which is to say, with the majority of approaches one finds in political animal studies today.

Indeed, particularly given the range of empirical insights Massumi brings into his account of animality, it is not with animal rights theory, but with certain strains within politically oriented natural science that What Animals Teach Us about Politics resonates best. Franz de Waal's Chimpanzee Politics: Power and Sex Among Apes caused a stir in the early 1980s when it revealed that political structures and dynamics long held to be exclusive to humans are in fact just as prevalent in the social lives of our closest living relatives. In so far as Massumi grounds his notion of animal politics in the playful, self-expressive nature of animality itself, then he would doubtless agree with de Waal's observation that 'the roots of politics are older than humanity' (1982, pp. 211-212). On both accounts, politics emerges in and from animal life, and is accordingly prior to, and not simply derivable from, the human domain. From this vantage, calls to extend political structures from humans to animals miss something fundamental about the nature of politics. I take it that Massumi's most powerful claim, though one he is not alone in defending, is not so much that animals teach us something valuable about politics, but that animality already lies at the core of our political lives and relationships.

\section{References}

De Waal, F. (1982) Chimpanzee Politics: Power and Sex Among Apes. New York: Harper \& Row. Donaldson, S. and Kymlicka, W. (2013) Zoopolis: A Political Theory of Animal Rights. Oxford: Oxford University Press.

David Alexander Craig University of Oregon, Eugene, OR 97403, USA davidalexandercraig@gmail.com 